\title{
ORGANIC GEOCHEMISTRY, DEPOSITIONAL ENVIRONMENT AND HYDROCARBON POTENTIAL OF THE TERTIARY OIL SHALE DEPOSITS IN NW ANATOLIA, TURKEY
}

\author{
R. KARA GÜLBAY*, S. KORKMAZ \\ Department of Geological Engineering \\ Karadeniz Technical University \\ 61080, Trabzon, Turkey
}

\begin{abstract}
In this study, organic geochemical characteristics and depositional environment of the Tertiary-aged oil shale deposits in Northwest Anatolia have been examined. Oil shales in all the studied areas are typically characterized by high hydrogen index and low oxygen index values. Beypazarı, Himmetoğlu, Gölpazarı and Bahçecik oil shales contain only Type I kerogen. Seyitömer and Hatzldağ shales contain dominantly Type I and minor amounts of Type II kerogen. Gas chromatography of Beypazarl and Seyitömer oil shales shows only $C_{17}$ and $C_{18}$ n-alkanes but no other n-alkanes. Gas chromatography of Himmetoğlu, Hatıldağ, Gölpazarı and Bahçecik oil shales shows a bimodal distribution dominated by low-number n-alkanes. Pristan/Phytan (Pr/Ph) ratios of the shales suggest an anoxic depositional environment for Beypazarl, Seyitömer and Hatıldăg and a suboxic environment for Himmetoğlu, Gölpazarı and Bahçecik oil shales. $T_{\max }$ values indicate that oil shales are immature. In addition to gas chromatograms, the biomarker parameters measured using $\mathrm{m} / \mathrm{z} 217$ and $\mathrm{m} / \mathrm{z} 191$ mass chromatograms indicate that the oil shales contain immature organic matter. Gammacerane, a typical biomarker for saline depositional environment, has been determined in all the oil shales. When other biomarker parameters are taken into account, it is apparent that all the shale samples have been deposited in a saline environment. In general, the data obtained by geochemical analyses indicate a lacustrine depositional environment for all of the shale samples in the studied areas.
\end{abstract}

\section{Introduction}

With a reserve of 1.6 billion tonnes, Turkey has a significant oil shale potential. The most important oil shale deposits are located in Beypazarı (Ankara), Seyitömer (Kütahya), Himmetoğlu and Hatıldağ (Bolu), Gölpazarı

\footnotetext{
* Corresponding author: e-mail kara@ktu.edu.tr
} 
(Bilecik) and Bahçecik (Izmit) (Fig. 1). The deposits are characterized by the following values for oil shale sequence thickness $(\mathrm{m})$ and reserves (million tonnes): Himmetoğlu -84 and 660 , Hatıldag $-26-120$ and 360 , Gölpazarı 46 and 120, Bahçecik - 38 and 40, Seyitömer - 8.5-50 and 120 and Beypazar1 - 57-111 and 330, respectively.

These oil shale deposits have been studied by numerous researchers. Geologic, geochemical and economic investigations of these fields have been conducted [1-9].

Geological and economic features of oil shale fields have been studied separately. In this study, organic geochemical characteristics (organic material content, maturity, type and biomarker distribution) of oil shale deposits in Western and Northwestern Anatolia, their depositional environments and hydrocarbon potentials are discussed. In addition, oil shale fields are also compared.

\section{Geological setting}

Listed above deposits in Tertiary basins are located in the western and northwestern regions of Turkey (Fig. 1). The Hatıldağ shale deposits are of Paleocene-Eocene [6], the Gölpazar1-Bahçecik deposits of Oligocene [1,2] and the Beypazar1-Seyitömer-Himmetoğlu deposits of Miocene age [3-5, 9].

Considering their geological characteristics, oil shale fields are located in four different regions. The Seyitömer field is located north of the Kütahya city. Upper Cretaceous ophiolitic mélange comprises the basement of the Seyitömer field. It is unconformably overlain by the Miocene clastic deposits. Oil shales within the Miocene deposits are alternated with lignite, claystone and limestones. The Miocene units in the basin are unconformably overlain by the Pliocene tuffs and claystones.

The Beypazarı field is located in the northwestern part of Ankara city. The basement is represented by the Paleozoic metamorphites. Tertiary deposits are unconformably set above the basement. Paleocene-Eocene is represented by red-colored clastic deposits. These units are unconformably overlain by the Miocene lignite and oil shale. The older deposits in the region are unconformably covered by the Pliocene units.

The Himmetoğlu, Hatıldağ and Gölpazarı oil shale fields are formed in the Bolu-Bilecik basin. The Gölpazarı field is located northwest of the Bilecik city and Himmetoğlu and Hatıldağ fields southeast of the Bolu city. Paleozoic metamorphites are the oldest rock units in the basin. They are unconformably covered by the Jurassic - Lower Cretaceous carbonate deposits. These units are unconformably overlain by thick turbiditic deposits of Late Cretaceous age which are widely distributed in the region. Oil shales in the basin are found in the Tertiary clastic deposits. Himmetoğlu oil shales are found in the Miocene deposits, Hatıldağ shales in the Paleocene-Eocene deposits and Gölpazarı shales are associated with the Oligocene deposits. 


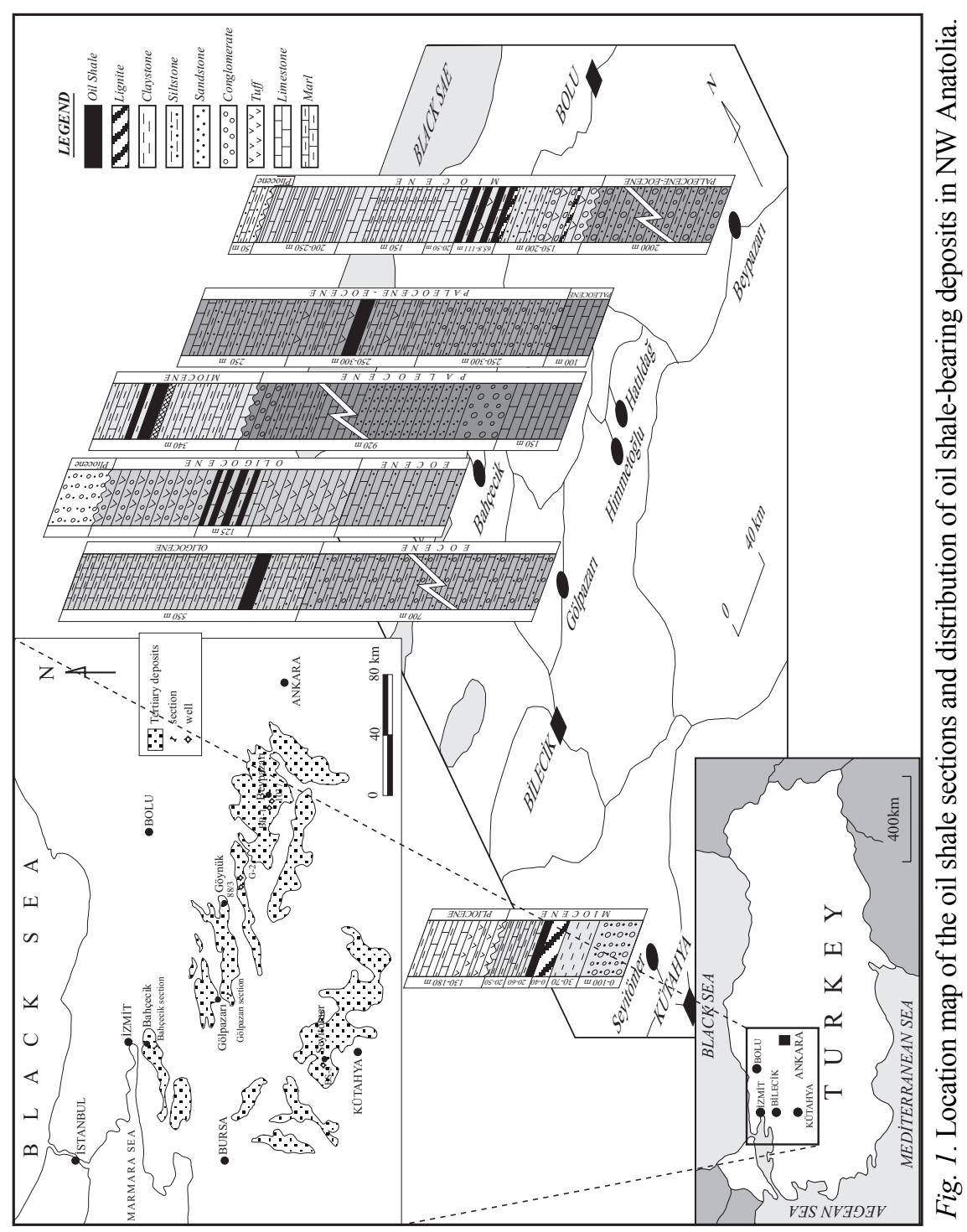


The Bahçecik field is located south of the İzmit city. Paleozoic rocks are the oldest rock units in the Bahçecik field. The basement is unconformably covered by Eocene sandstones and limestones. Oil shales alternate with Oligocene marl, shale and tuff. Pliocene loose pebbles and sands are unconformably set above these units.

\section{Materials and methods}

The oil shale samples from Beypazarı, Seyitömer, Himmetoğlu and Hatıldağ areas are taken from the well cores obtained from MTA (General Directorate of Mineral Research and Exploration). In the Gölpazar1 and Bahçecik areas, a systematic sampling through the stratigraphic sections was carried out.

Pyrolysis/TOC, extraction, column chromatography, gas chromatography (GC) and gas chromatography-mass spectrometry (GC-MS) were conducted on selected oil shale samples at TPAO (Turkish Petroleum Corp.) Research Center's Organic Geochemistry Laboratories.

Total organic carbon (TOC) and Rock-Eval pyrolysis were performed on $100 \mathrm{mg}$ crushed rock samples which were heated to $600{ }^{\circ} \mathrm{C}$ in the helium atmosphere, using a TOC module equipped Rock-Eval II type instrument.

For extraction of the $\mathrm{C}_{15^{+}}$-soluble organic matter (SOM), samples were treated with dichlorometane $\left(\mathrm{CH}_{2} \mathrm{Cl}_{2}\right)$ for $40 \mathrm{~h}$ in a Soxhlet apparatus. Extracts were seperated into saturated hydrocarbon, aromatic hydrocarbon and NSO-compound fractions by liquid chromatography. Fractions of saturated hydrocarbons were dissolved in hexane and analysed by a Varian 3400 gas chromatograph, equipped with a flame photometric dedector (FPD) and a flame ionisation dedector (FID). A fused capillary column $(60 \mathrm{~m}$ $0.20 \mathrm{~mm}$ i.d.) coated with cross-linked dimethylpolysiloxane (J8N, $0.25 \mu \mathrm{m}$ film thickness) was used. Helium was used as a carrier gas. The oven temperature was programmed from 40 (initial hold-up time $8 \mathrm{~min}$ ) to $270{ }^{\circ} \mathrm{C}$ (initial hold-up time $60 \mathrm{~min}$ ) at $4{ }^{\circ} \mathrm{C} / \mathrm{min}$.

For GC-MS analysis, a MAT GCQ-Ion trap mass spectrometer was used that was coupled to a Trace-2000 gas chromatograph. The gas chromatograph was equipped with a DB-1 fused silica capillary column of $60-\mathrm{m}$ length, $0.25-\mathrm{mm}$ inner diameter and $0.25-\mu \mathrm{m}$ film thickness. Helium was used as a carrier gas. The oven temperature was programmed from $50{ }^{\circ} \mathrm{C}$ (initial hold-up time $10 \mathrm{~min}$ ) to $200^{\circ} \mathrm{C}$ (initial hold-up time $15 \mathrm{~min}$.) at $10{ }^{\circ} \mathrm{C} / \mathrm{min}$, to $250{ }^{\circ} \mathrm{C}$ (initial hold-up time $24 \mathrm{~min}$ ) at $5^{\circ} \mathrm{C} / \mathrm{min}$ and then to $280^{\circ} \mathrm{C}$ (initial hold-up time $24 \mathrm{~min}$ ) at $2{ }^{\circ} \mathrm{C} / \mathrm{min}$. Finally, the oven temperature was increased to $290{ }^{\circ} \mathrm{C}$ (initial hold-up time $37 \mathrm{~min}$ ) at $1{ }^{\circ} \mathrm{C} / \mathrm{min}$. The mass spectrometer was operated in EI mode at an ionization energy of $70 \mathrm{eV}$ and a source temperature of $230{ }^{\circ} \mathrm{C}$. For the analysis of biomarkers, metastable ion transition for sterans $(\mathrm{m} / \mathrm{z} 217)$ and triterpanes $(\mathrm{m} / \mathrm{z} 191)$ was recorded at a dwell time of $25 \mathrm{~ms}$ per ion and a cycle time of $1 \mathrm{~s}$. 
Compounds were identified through retention time. Triterpane and sterane distributions were quantified by measuring peak heights in the $\mathrm{m} / \mathrm{z} 191$ and $\mathrm{m} / \mathrm{z} 217$ chromatograms for saturated hydrocarbons, respectively. The peaks recorded in chromatograms are defined in Tables 1 and 2.

Table 1. Peak definitions of steranes of $\mathbf{~ m / z ~} 217$ mass chromatograms

\begin{tabular}{|c|c|}
\hline Peak No & Compound \\
\hline 1 & $\mathrm{C}_{27} 13 \beta(\mathrm{H}), 17 \alpha(\mathrm{H})$-Diasterane (20S) \\
\hline 2 & $\mathrm{C}_{27} 13 \beta(\mathrm{H}), 17 \alpha(\mathrm{H})$-Diasterane (20R) \\
\hline 3 & $\mathrm{C}_{27} 13 \alpha(\mathrm{H}), 17 \beta(\mathrm{H})$-Diasterane (20S) \\
\hline 4 & $\mathrm{C}_{27} 13 \alpha(\mathrm{H}), 17 \beta(\mathrm{H})$-Diasterane (20R) \\
\hline 5 & $\mathrm{C}_{28} 13 \beta(\mathrm{H}), 17 \alpha(\mathrm{H})$-Diasterane (20S) \\
\hline 6 & $\mathrm{C}_{28} 13 \beta(\mathrm{H}), 17 \alpha(\mathrm{H})$-Diasterane (20R) \\
\hline 7 & $\mathrm{C}_{28} 13 \alpha(\mathrm{H}), 17 \beta(\mathrm{H})$-Diasterane (20S) \\
\hline 8 & $\mathrm{C}_{27} 5 \alpha(\mathrm{H}), 14 \alpha(\mathrm{H}), 17 \alpha(\mathrm{H})-$ Sterane $(20 \mathrm{~S})+$ \\
\hline & $\mathrm{C}_{28} 13 \alpha(\mathrm{H}), 17 \beta(\mathrm{H})$-Diasterane (20S) \\
\hline 9 & $\mathrm{C}_{27} 5 \alpha(\mathrm{H}), 14 \beta(\mathrm{H}), 17 \beta(\mathrm{H})$ - Sterane $(20 \mathrm{R})+$ \\
\hline & $\mathrm{C}_{29} 13 \beta(\mathrm{H}), 17 \alpha(\mathrm{H})$-Diasterane $(20 \mathrm{~S})$ \\
\hline 10 & $\mathrm{C}_{27} 5 \alpha(\mathrm{H}), 14 \beta(\mathrm{H}), 17 \beta(\mathrm{H})$ - Sterane $(20 \mathrm{~S})+$ \\
\hline & $\mathrm{C}_{28} 13 \alpha(\mathrm{H}), 17 \beta(\mathrm{H})$-Diasterane (20R) \\
\hline 11 & $\mathrm{C}_{27} 5 \alpha(\mathrm{H}), 14 \alpha(\mathrm{H}), 17 \alpha(\mathrm{H})-$ Sterane (20R) \\
\hline 12 & $\mathrm{C}_{29} 13 \beta(\mathrm{H}), 17 \alpha(\mathrm{H})$-Diasterane (20R) \\
\hline 13 & $\mathrm{C}_{29} 13 \alpha(\mathrm{H}), 17 \beta(\mathrm{H})$-Diasterane (20S) \\
\hline 14 & $\mathrm{C}_{28} 5 \alpha(\mathrm{H}), 14 \alpha(\mathrm{H}), 17 \alpha(\mathrm{H})-$ Sterane $(20 \mathrm{~S})$ \\
\hline 15 & $\mathrm{C}_{28} 5 \alpha(\mathrm{H}), 14 \beta(\mathrm{H}), 17 \beta(\mathrm{H})$-Sterane $(20 \mathrm{R})+\mathrm{C}_{29}$ \\
\hline 16 & $\mathrm{C}_{28} 5 \alpha(\mathrm{H}), 14 \beta(\mathrm{H}), 17 \beta(\mathrm{H})$ - Sterane (20S) \\
\hline 17 & $\mathrm{C}_{28} 5 \alpha(\mathrm{H}), 14 \alpha(\mathrm{H}), 17 \alpha(\mathrm{H})-$ Sterane (20R) \\
\hline 18 & $\mathrm{C}_{29} 5 \alpha(\mathrm{H}), 14 \alpha(\mathrm{H}), 17 \alpha(\mathrm{H})-$ Sterane $(20 \mathrm{~S})$ \\
\hline 19 & $\mathrm{C}_{29} 5 \alpha(\mathrm{H}), 14 \beta(\mathrm{H}), 17 \beta(\mathrm{H})$ - Sterane (20R) \\
\hline 20 & $\mathrm{C}_{29} 5 \alpha(\mathrm{H}), 14 \beta(\mathrm{H}), 17 \beta(\mathrm{H})-$ Sterane (20S) \\
\hline 21 & $\mathrm{C}_{29} 5 \alpha(\mathrm{H}), 14 \alpha(\mathrm{H}), 17 \alpha(\mathrm{H})-$ Sterane (20R) \\
\hline 22 & $\mathrm{C}_{30} 5 \alpha(\mathrm{H}), 14 \alpha(\mathrm{H}), 17 \alpha(\mathrm{H})-$ Sterane $(20 \mathrm{~S})$ \\
\hline
\end{tabular}

Table 2. Peak definitions of tritepanes of $\mathbf{m} / \mathbf{z} 191$ mass chromatograms

\begin{tabular}{|c|l|}
\hline Peak No & \multicolumn{1}{|c|}{ Compound } \\
\hline 1 & $\mathrm{C}_{19}$ Tricyclic Terpane \\
2 & $\mathrm{C}_{20}$ Tricyclic Terpane \\
3 & $\mathrm{C}_{21}$ Tricyclic Terpane \\
4 & $\mathrm{C}_{22}$ Tricyclic Terpane \\
5 & $\mathrm{C}_{23}$ Tricyclic Terpane \\
& $(18,19-$ Bisnor-13ß $(\mathrm{H}), 14 \alpha(\mathrm{H})$ Cheilanthaneane) \\
6 & $\mathrm{C}_{24}$ Tricyclic Terpane \\
7 & $\mathrm{C}_{25}(22 \mathrm{~S}+22 \mathrm{R})$ Tricyclic Terpane \\
8 & Tetracyclic Hopane (Secohopane) \\
9 & $\mathrm{C}_{26} 22(\mathrm{~S})$ Tricyclic Terpane \\
10 & $\mathrm{C}_{26}$ 22(R) Tricyclic Terpane \\
11 & $\mathrm{C}_{28}$ Tricyclic Terpane \\
12 & $\mathrm{C}_{29}$ Tricyclic Terpane \\
\hline
\end{tabular}




\begin{tabular}{|c|c|}
\hline Peak No & Compound \\
\hline 13 & $\mathrm{C}_{27} 18 \alpha(\mathrm{H})-22,29,30$-Trisnorneohopane (Ts) \\
\hline 14 & $\mathrm{C}_{27} 17 \alpha(\mathrm{H})-22,29,30$-Trisnorhopane $(\mathrm{Tm})$ \\
\hline 16 & $\mathrm{C}_{30}$ Tricyclic Terpane \\
\hline 18 & $\mathrm{C}_{29} 17 \alpha(\mathrm{H}), 21 \beta(\mathrm{H})-30$-Norhopane \\
\hline 19 & $\mathrm{C}_{29}$ Ts $(18 \alpha(\mathrm{H})-30$-Norneohopane \\
\hline 21 & $\mathrm{C}_{29} 17 \beta(\mathrm{H}), 21 \alpha(\mathrm{H})$-30-Normoretane \\
\hline 22 & Oleanane \\
\hline 23 & $\mathrm{C}_{30} 17 \alpha(\mathrm{H}), 21 \beta(\mathrm{H})-$ Hopane \\
\hline 24 & $\mathrm{C}_{30} 17 \beta(\mathrm{H}), 21 \alpha(\mathrm{H})$-Moretane \\
\hline 25 & $\mathrm{C}_{31} 17 \alpha(\mathrm{H}), 21 \beta(\mathrm{H})-30-$ Homohopane (22S) \\
\hline 26 & $\mathrm{C}_{31} 17 \alpha(\mathrm{H}), 21 \beta(\mathrm{H})-30$-Homohopane (22R) \\
\hline 27 & Gammacerane \\
\hline 28 & Homomoretane \\
\hline 29 & $\mathrm{C}_{32} 17 \alpha(\mathrm{H}), 21 \beta(\mathrm{H})-30,31$-Bishomohopane (22S) \\
\hline 30 & $\mathrm{C}_{32} 17 \alpha(\mathrm{H}), 21 \beta(\mathrm{H})-30,31$-Bishomohopane (22R) \\
\hline 31 & $\mathrm{C}_{33} 17 \alpha(\mathrm{H}), 21 \beta(\mathrm{H})-30,31,32$-Trishomohopane (22S) \\
\hline 32 & $\mathrm{C}_{33} 17 \alpha(\mathrm{H}), 21 \beta(\mathrm{H})-30,31,32$-Trishomohopane (22R) \\
\hline 33 & $\mathrm{C}_{34} 17 \alpha(\mathrm{H}), 21 \beta(\mathrm{H})-30,31,32,33$-Tetrakishomohopane (22S) \\
\hline 34 & $\mathrm{C}_{34} 17 \alpha(\mathrm{H}), 21 \beta(\mathrm{H})-30,31,32,33$-Tetrakishomohopane (22R) \\
\hline 35 & $\mathrm{C}_{35} 17 \alpha(\mathrm{H}), 21 \beta(\mathrm{H})-30,31,32,33,34-P e n t a k i s h o m o h o p a n e ~(22 \mathrm{~S})$ \\
\hline 36 & $\mathrm{C}_{35} 17 \alpha(\mathrm{H}), 21 \beta(\mathrm{H})-30,31,32,33,34$-Pentakishomohopane (22R) \\
\hline
\end{tabular}

\section{Results and discussion}

\section{Total organic carbon (TOC) and Rock-Eval pyrolysis}

The total organic carbon (TOC) values (average) of the Beypazarı, Seyitömer, Himmetoğlu, Hatıldağ, Gölpazarı and Bahçecik oil shale samples are $8.91 ; 9.17 ; 15.81 ; 4.75 ; 5.17$ and 7.15 wt.\%, respectively (Table 3 ). The TOC values of the Beypazarı, Seyitömer and Himmetoğlu oil shale samples show a large variation. On the other hand, the samples from the other areas show a more or less homogenous TOC distribution.

Hydrogen index (HI) values obtained from Rock-Eval analysis are exceptionally high, but oxygen index (OI) values are low as it is expected in oil shale samples. The average HI values of Beypazar1, Seyitömer, Himmetoğlu, Hatıldağ, Gölpazarı and Bahçecik oil shales are 822, 648, 723, $720,781,812 \mathrm{mg} \mathrm{HC} / \mathrm{g} \mathrm{TOC}$, and their average OI values are $30,55,39,30$, $43,15 \mathrm{mg} \mathrm{CO} / \mathrm{g}$ TOC, respectively.

$\mathrm{S}_{1}, \mathrm{~S}_{2}$ and $\mathrm{S}_{3}$ values are also measured by using a Rock-Eval analyzer. The ratio of $\mathrm{S}_{2} / \mathrm{S}_{3}$ gives an idea about the kerogen type. Potential yield (PY) $\left(\mathrm{S}_{1}+\mathrm{S}_{2}\right)$ values are the reflection of hydrocarbon potential of a rock sample, and finally production index (PI) $\left[\mathrm{S}_{1} /\left(\mathrm{S}_{1}+\mathrm{S}_{2}\right)\right]$ ratio is used for maturity evaluation. In the studied samples, generally, $\mathrm{S}_{2} / \mathrm{S}_{3}$ ratios and $\mathrm{PY}$ values are relatively high and PI are low (Table 3 ).

The $T_{\max }$ values, which are measured by the the Rock-Eval analyzer and show the maturity level of the organic matter are, on average, 429, 423, 432, 
436, 431 and $442{ }^{\circ} \mathrm{C}$ for the Beypazarı, Seyitömer, Himmetoğlu, Hatıldağ, Gölpazarı and Bahçecik oil shale samples, respectively.

Table 3. Results of Rock-Eval/TOC analyses

\begin{tabular}{|c|c|c|c|c|c|c|c|c|c|c|c|c|}
\hline $\begin{array}{l}\text { Sample } \\
\text { No }\end{array}$ & $\underset{(\mathrm{m})}{\text { Depth }}$ & $\begin{array}{c}\text { TOC } \\
(\%)\end{array}$ & $\underset{\text { (mgHC/g rock) }}{\mathrm{S}_{1}}$ & $\underset{\text { (mgHC/g rock) }}{\mathrm{S}_{2}}$ & $\begin{array}{c}\mathrm{S}_{3} \\
\text { (mgCO } / \mathrm{g} \mathrm{rock})\end{array}$ & $\begin{array}{c}\text { Kerogen } \\
\text { Type } \\
\mathrm{S}_{2} / \mathrm{S}_{3}\end{array}$ & $\begin{array}{c}(\mathrm{PY}) \\
\mathrm{S}_{1}+\mathrm{S}_{2} \\
\text { (mgHC/g rock) }\end{array}$ & $\begin{array}{c}(\mathrm{PI}) \\
\mathrm{S}_{1} /\left(\mathrm{S}_{1}+\mathrm{S}_{2}\right)\end{array}$ & $\begin{array}{l}\mathrm{T}_{\max } \\
\left({ }^{\circ} \mathrm{C}\right)\end{array}$ & $\begin{array}{c}(\mathrm{HI}) \\
\mathrm{S}_{2} / \mathrm{TOC} \\
(\mathrm{mgHC} / \mathrm{g} \text { TOC) }\end{array}$ & $\begin{array}{c}(\mathrm{OI}) \\
\mathrm{S}_{3} / \mathrm{TOC} \\
\left(\mathrm{mgCO}_{2} / \mathrm{g} \mathrm{TOC}\right)\end{array}$ & $\begin{array}{l}\text { Residual } \\
\text { Carbon }\end{array}$ \\
\hline \multicolumn{13}{|c|}{ BB-1 Well (Beypazart-Ankara) } \\
\hline ABB-1 & 50.35 & 1.85 & 2.16 & 14.37 & 1.13 & 12.72 & 16.53 & 0.13 & 428 & 776 & 61 & 0.48 \\
\hline ABB-4 & 85.60 & 18.01 & 7.54 & 145.84 & 6.41 & 22.75 & 153.38 & 0.05 & 438 & 809 & 35 & 5.23 \\
\hline ABB-5 & 95.50 & 6.47 & 7.70 & 54.02 & 1.69 & 31.96 & 61.72 & 0.12 & 433 & 834 & 26 & 1.33 \\
\hline ABB-6 & 99.65 & 8.95 & 5.61 & 76.11 & 1.58 & 48.17 & 81.72 & 0.07 & 426 & 850 & 17 & 2.14 \\
\hline ABB-8 & 108.20 & 5.98 & 3.33 & 53.54 & 1.40 & 38.24 & 56.87 & 0.05 & 437 & 895 & 23 & 1.25 \\
\hline ABB-10 & 113.90 & 7.92 & 6.04 & 62.43 & 1.88 & 33.21 & 68.47 & 0.09 & 411 & 788 & 23 & 2.22 \\
\hline \multicolumn{13}{|c|}{1037 Well (Beypazart-Ankara) } \\
\hline BP-2 & 994.30 & 12.58 & 6.36 & 115.80 & 3.88 & 29.85 & 122.16 & 0.05 & 437 & 913 & 30 & 2.50 \\
\hline BP-9 & 165.30 & 9.52 & 3.61 & 67.49 & 2.21 & 30.54 & 71.10 & 0.05 & 423 & 708 & 23 & 3.60 \\
\hline Average & & 8.91 & 5.29 & 73.7 & 2.52 & 30.93 & 78.99 & 0.08 & 429 & 822 & 30 & 2.34 \\
\hline \multicolumn{13}{|c|}{ BS-5 Well (Seyitömer-Kütahya) } \\
\hline KS-4 & 46.00 & 3.09 & 1.57 & 21.84 & 2.03 & 10.76 & 23.41 & 0.07 & 421 & 706 & 65 & 1.14 \\
\hline KS-5 & 52.80 & 6.46 & 3.34 & 42.46 & 3.14 & 13.52 & 45.80 & 0.07 & 425 & 657 & 48 & 2.65 \\
\hline KS-7 & 61.50 & 2.22 & 1.16 & 15.70 & 1.30 & 12.08 & 16.86 & 0.07 & 424 & 707 & 58 & 0.82 \\
\hline KS-8 & 62.50 & 24.92 & 14.28 & 130.49 & 12.07 & 10.81 & 114.77 & 0.10 & 421 & 523 & 48 & 12.86 \\
\hline Average & & 9.17 & 5.09 & 52.62 & 4.64 & 11.79 & 50.21 & 0.08 & 423 & 648 & 55 & 4.37 \\
\hline \multicolumn{13}{|c|}{ 88/3 Well (Himmetoğlu-Bolu) } \\
\hline BH-2 & 15.70 & 3.02 & 1.43 & 19.51 & 1.96 & 9.95 & 20.94 & 0.07 & 430 & 646 & 64 & 1.28 \\
\hline BH-5 & 64.50 & 5.85 & 1.89 & 45.54 & 2.18 & 20.89 & 47.43 & 0.04 & 436 & 778 & 37 & 1.90 \\
\hline BH-7 & 81.40 & 11.64 & 2.60 & 87.37 & 4.37 & 19.99 & 89.97 & 0.03 & 433 & 750 & 37 & 4.15 \\
\hline BH-8 & 86.50 & 35.58 & 14.30 & 287.21 & 9.33 & 30.78 & 301.51 & 0.05 & 433 & 807 & 26 & 10.46 \\
\hline BH-10 & 93.55 & 10.61 & 3.32 & 70.57 & 4.55 & 15.51 & 73.89 & 0.04 & 433 & 665 & 42 & 4.46 \\
\hline BH-12 & 100.30 & 28.14 & 15.73 & 194.93 & 8.15 & 23.92 & 210.66 & 0.07 & 424 & 692 & 28 & 10.59 \\
\hline Average & & 15.81 & 6.55 & 117.52 & 5.09 & 20.17 & 124.07 & 0.05 & 432 & 723 & 39 & 5.47 \\
\hline \multicolumn{13}{|c|}{ G-2 Well (Hattldăg-Bolu) } \\
\hline BHD-1 & 58.00 & 2.04 & 0.94 & 12.54 & 0.93 & 13.48 & 13.48 & 0.07 & 427 & 614 & 45 & 0.92 \\
\hline BHD-4 & 121.50 & 2.53 & 0.23 & 18.66 & 0.87 & 21.45 & 18.89 & 0.01 & 442 & 737 & 34 & 0.96 \\
\hline BHD-5 & 166.65 & 8.26 & 1.06 & 62.96 & 1.49 & 42.26 & 64.02 & 0.02 & 441 & 762 & 18 & 2.93 \\
\hline BHD-7 & 191.60 & 6.48 & 2.27 & 58.88 & 1.12 & 52.57 & 61.15 & 0.04 & 440 & 908 & 17 & 1.39 \\
\hline BHD-9 & 207.00 & 3.84 & 0.46 & 13.64 & 1.34 & 10.18 & 14.10 & 0.03 & 427 & 355 & 34 & 2.67 \\
\hline BHD-10 & 221.00 & 5.36 & 2.80 & 50.52 & 1.81 & 27.91 & 53.32 & 0.05 & 437 & 942 & 33 & 0.92 \\
\hline Average & & 4.75 & 1.29 & 36.2 & 1.26 & 27.98 & 37.49 & 0.04 & 436 & 720 & 30 & 1.63 \\
\hline \multicolumn{13}{|c|}{ Gölpazarı (Bilecik) measured stratigraphical section } \\
\hline BG-8 & 44.70 & 3.21 & 0.63 & 23.46 & 1.60 & 14.66 & 24.09 & 0.03 & 432 & 730 & 49 & 1.21 \\
\hline BG-7 & 35.60 & 2.54 & 0.77 & 20.36 & 0.77 & 26.44 & 21.13 & 0.04 & 428 & 801 & 30 & 0.78 \\
\hline BG-6 & 31.25 & 2.06 & 0.53 & 14.00 & 1.38 & 10.14 & 14.53 & 0.04 & 426 & 679 & 66 & 0.85 \\
\hline BG-4 & 20.00 & 10.16 & 3.56 & 92.04 & 2.82 & 32.64 & 95.60 & 0.04 & 442 & 905 & 27 & 2.20 \\
\hline BG-2 & 10.15 & 10.34 & 3.25 & 83.33 & 3.13 & 26.62 & 86.58 & 0.04 & 435 & 805 & 30 & 3.13 \\
\hline BG-1 & 4.55 & 2.71 & 1.15 & 20.79 & 1.44 & 14.44 & 21.94 & 0.05 & 420 & 767 & 53 & 0.89 \\
\hline Average & & 5.17 & 1.65 & 42.33 & 1.86 & 20.82 & 43.98 & 0.04 & 431 & 781 & 43 & 1.51 \\
\hline \multicolumn{13}{|c|}{ Bahçecik (İmit) measured stratigraphical section } \\
\hline İB-12 & 33.50 & 6.26 & 1.73 & 46.82 & 1.20 & 39.02 & 48.55 & 0.04 & 440 & 747 & 19 & 2.22 \\
\hline İB-8 & 21.70 & 7.24 & 2.49 & 58.50 & 0.85 & 68.82 & 60.99 & 0.04 & 443 & 808 & 11 & 2.16 \\
\hline İB-7 & 19.10 & 9.19 & 2.37 & 66.94 & 1.75 & 38.25 & 69.31 & 0.03 & 436 & 728 & 19 & 3.42 \\
\hline İB-5 & 9.90 & 9.20 & 2.51 & 76.35 & 1.13 & 67.57 & 78.86 & 0.03 & 442 & 829 & 12 & 2.63 \\
\hline İB-2 & 4.60 & 6.27 & 1.50 & 57.31 & 0.78 & 73.47 & 58.81 & 0.03 & 448 & 914 & 12 & 1.37 \\
\hline İB-1 & 3.40 & 4.72 & 0.71 & 40.00 & 0.86 & 46.51 & 40.71 & 0.02 & 444 & 847 & 18 & 1.33 \\
\hline Average & & 7.15 & 1.89 & 57.65 & 1.10 & 55.61 & 59.54 & 0.03 & 442 & 812 & 15 & 2.19 \\
\hline
\end{tabular}




\section{Composition}

The extraction analysis is performed on 11 samples selected from different areas. Total bitumen amounts are divided according to TOC values which indicate expulsion efficiency, and maturity of the samples is generally low (varies from 0.024 to 0.073 ). Only the value from the Beypazar1 oil shale sample $(0.116)$ is relatively high compared to the other samples.

\section{n-Alkanes and isoprenoids}

Only $\mathrm{C}_{17}$ and $\mathrm{C}_{18} n$-alkanes are recorded in the gas chromatograms of the Seyitömer and Beypazarı oil shale samples (Fig. 2a-b). Isoprenoids are dominant in the gas chromatograms. High peak intensity is observed in the biomarker region.
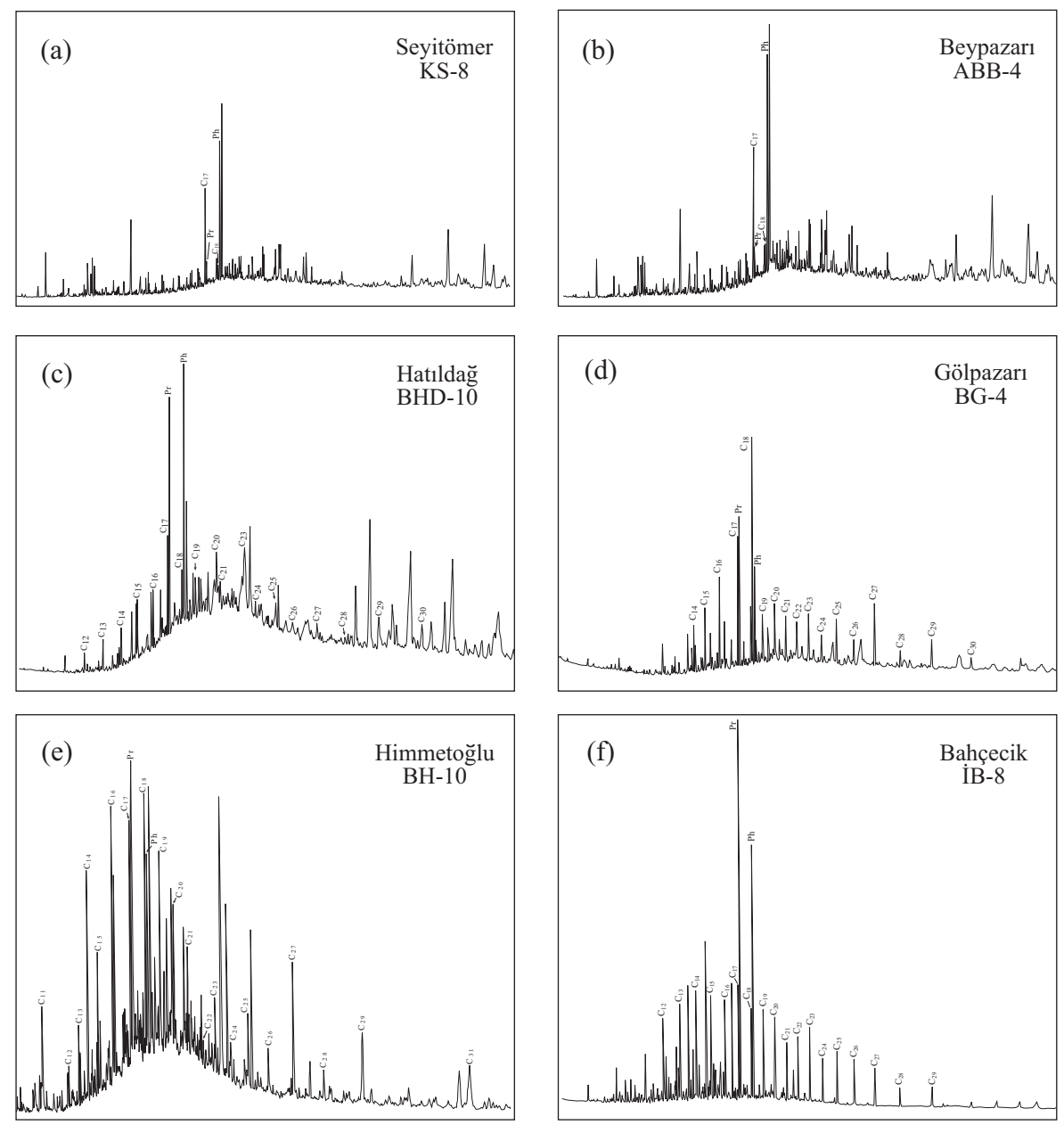

Fig. 2. Gas chromatograms of the selected oil shale samples. 
A bimodal distribution, where the $n$-alkanes with low carbon number are dominant, is generally observed in the gas chromatograms of the extracts obtained from the Himmetoğlu, Hatıldağ, Gölpazarı and Bahçecik oil shale samples (Fig. 2c-d-e-f). Gas chromatograms of the Gölpazarı and Himmetoğlu oil shale extracts show a bimodal distribution where $\mathrm{C}_{18}$ and $\mathrm{C}_{23}$ are the center, the maximum peak belonging to $\mathrm{C}_{18} n$-alkane. $\mathrm{C}_{17}$ is the maximum $n$-alkane peak in the gas chromatograms from the Hatıldağ and Bahçecik oil shales, and a bimodal distribution with $\mathrm{C}_{17}$ and $\mathrm{C}_{23}$ in the center is observed. The $n$-alkanes are the dominant peaks in the gas chromatograms from the Himmetoğlu and Hatıldağ oil shale samples, and isoprenoids are widely observed (Fig. 2c-e). The $n$-alkanes are the dominant peaks in the gas chromatograms from the Gölpazarı and Bahçecik oil shale samples (Fig. 2d-f).

The Carbon Preference Index (CPI) values are calculated in $\mathrm{C}_{24}-\mathrm{C}_{34}$ $\left\{\left[\left(\mathrm{C}_{25}+\mathrm{C}_{27}+\mathrm{C}_{29}+\mathrm{C}_{31}+\mathrm{C}_{33}\right) /\left(\mathrm{C}_{26}+\mathrm{C}_{28}+\mathrm{C}_{30}+\mathrm{C}_{32}+\mathrm{C}_{34}\right)+\left(\mathrm{C}_{25}+\mathrm{C}_{27}+\mathrm{C}_{29}+\mathrm{C}_{31}+\mathrm{C}_{33}\right) /\right.\right.$ $\left.\left.\left(\mathrm{C}_{24}+\mathrm{C}_{26}+\mathrm{C}_{28}+\mathrm{C}_{30}+\mathrm{C}_{32}\right)\right] / 2\right\}$ and $\mathrm{C}_{22}-\mathrm{C}_{30} \quad\left\{2\left(\mathrm{C}_{23}+\mathrm{C}_{25}+\mathrm{C}_{27}+\mathrm{C}_{29}\right) /\left[\mathrm{C}_{22}+2\left(\mathrm{C}_{24}+\right.\right.\right.$ $\left.\mathrm{C}_{26}+\mathrm{C}_{28}\right)+\mathrm{C}_{30}$ ] $\}$ [20] ranges from the gas chromatograms of the Bahçecik, Gölpazarı, Hatıldağ and Himmetoğlu oil shale samples and these CPI values are $1.36,1.31 ; 1.76,1.68 ; 2.29,1.48$ and $3.60,1.55$, respectively. CPI values are evidently higher than 1.0 for all oil shale samples, which means that the odd number $n$-alkanes are dominant.

The pristane/phytane ( $\mathrm{Pr} / \mathrm{Ph})$ ratios calculated for the Beypazar1, Seyitömer, Himmetoğlu, Hatıldağ, Gölpazarı and Bahçecik oil shale samples are $0.14 ; 0.17 ; 1.47 ; 0.93 ; 1.54$ and 1.52 , respectively.

\section{Biomarkers}

The m/z 217 and m/z 191 mass chromatograms showing the sterane and triterpane distributions in the oil shale samples from different areas are presented in Figs. 3 and 4; the peaks recorded in chromatograms are defined in Tables 1 and 2.

Many biomarker parameters, which are used to find different characteristics of the organic matter, are obtained by using the sterane and triterpane distributions (Table 4). In general, when the sterane distributions belonging to different areas are studied, it is observed that $\mathrm{C}_{29}$ is the dominant sterane in the Bahçecik, Beypazarı, Gölpazarı and Seyiömer oil shales. As for the Himmetoğlu and Hatıldağ oil shales, $\mathrm{C}_{27}$ is observed as a dominant sterane, but $\mathrm{C}_{29}$ sterane shows values close to $\mathrm{C}_{27}$. Considering that $\mathrm{C}_{27}$ steranes are recorded together with diasteranes in $\mathrm{m} / \mathrm{z} 217$ mass chromatograms, it can be concluded that $\mathrm{C}_{29}$ sterane is probably a little bit more dominant in these oil shales. Traces of $\mathrm{C}_{30}$ sterane are recorded only for the Seyitömer oil shales (Fig. 3e), as for the $\mathrm{m} / \mathrm{z} 217$ mass chromatograms from the other shales, $\mathrm{C}_{30}$ sterane is not recorded. While the isosteranes are dominant in comparison to the normal and rearranged steranes in the Beypazarı and Seyitömer oil shales, very high ratios of the normal steranes and rather low ratios of the rearranged steranes characterize the Himmetoğlu, Hatıldağ, Gölpazarı and Bahçecik oil shales. The diasterane/sterane ratios 

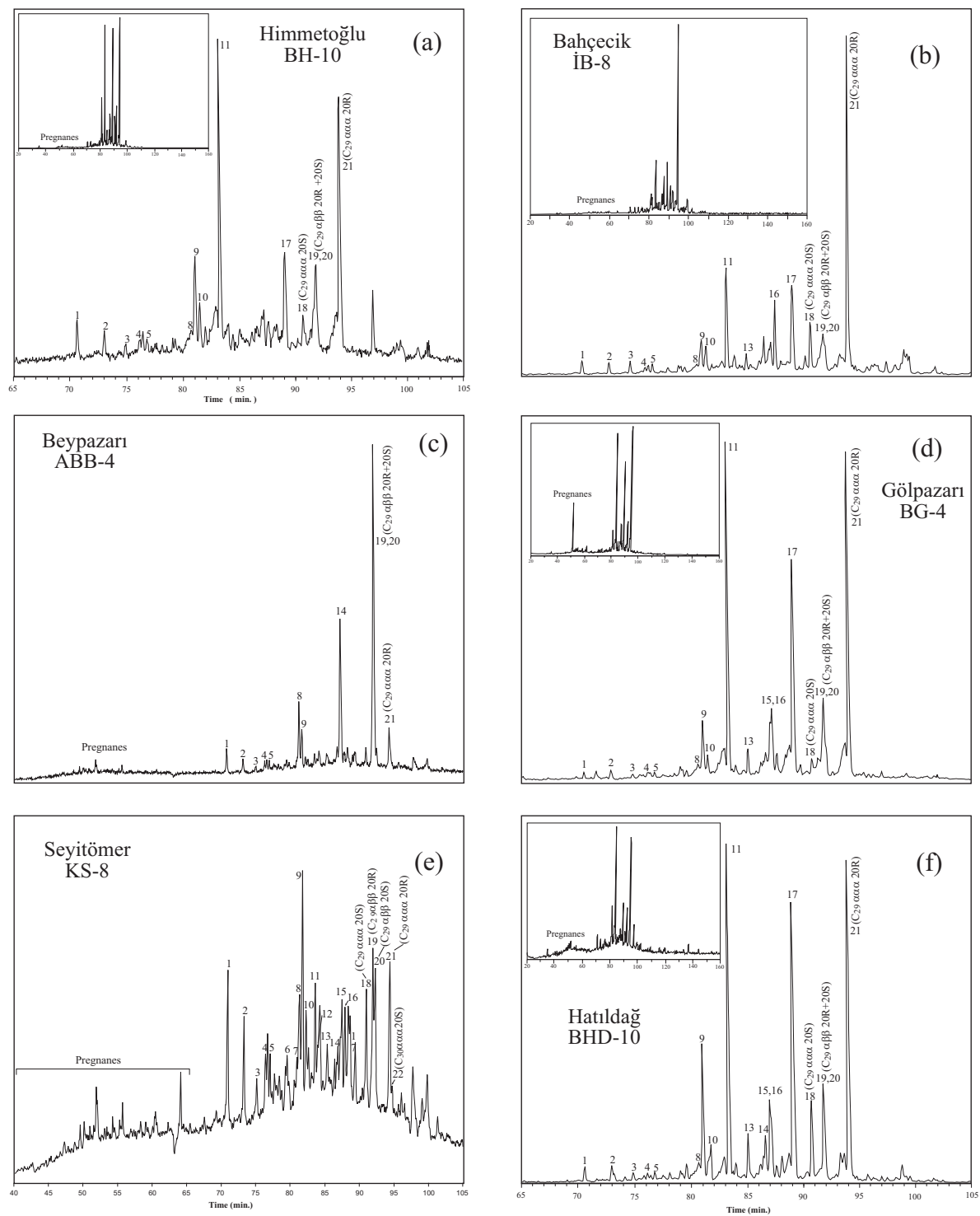

Fig. 3. The $\mathrm{m} / \mathrm{z} 217$ mass chromatograms of the selected oil shales (for peak definition see Table 1).

are generally very low (Table 4). Diasteranes are widely observed only in the Seyitömer oil shales.

The m/z 191 mass chromatograms of oil shales from all areas show low concentrations of tricyclic terpane. $\operatorname{Tm}\left(\mathrm{C}_{27} 17 \alpha(\mathrm{H})\right.$-22,29,30-trisnorhopane) is more dominant than $\mathrm{Ts}_{\mathrm{C}}\left(\mathrm{C}_{27} 18 \alpha(\mathrm{H})-22,29,30\right.$-trisnorneophane $)$ in all oil shale samples. The Seyitömer oil shale sample contains more $\mathrm{C}_{29}$ norhopane than $\mathrm{C}_{30}$ hopane, and $\mathrm{C}_{30}$ hopane is more dominant in the samples of the other areas. Low amounts of the oleanane are recorded in the Hatıldağ, 
Table 4. Biomarker parameters calculated from m/z 217 and m/z 191 mass chromatograms

\begin{tabular}{|c|c|c|c|c|c|c|}
\hline \multirow[t]{2}{*}{ Parameters } & \multicolumn{6}{|c|}{ Field name } \\
\hline & Beypazarı & Seyitömer & Himmetoğlu & Hatıldağ & Gölpazarı & Bahçecik \\
\hline $\mathrm{C}_{35} /\left(\mathrm{C}_{31}-\mathrm{C}_{35}\right)$ & & & & & & \\
\hline Homohopane Index & nd & $9 \%$ & $12 \%$ & $15 \%$ & $15 \%$ & $2 \%$ \\
\hline $\begin{array}{l}\mathrm{C}_{35} / \mathrm{C}_{34} \text { Homo- } \\
\text { hopane Ratio }\end{array}$ & nd & 0.83 & nd & 0.91 & nd & 0.45 \\
\hline $\mathrm{C}_{25} / \mathrm{C}_{26}$ & & & & & & \\
\hline $\begin{array}{l}\text { Tricyclic Terpane } \\
\text { Ratio }\end{array}$ & nd & nd & nd & 0.82 & nd & nd \\
\hline $\begin{array}{l}\text { Gammaceran Index } \\
{\left[\text { Gammacerane } / \mathrm{C}_{30}\right.}\end{array}$ & 0.13 & 0.54 & 0.32 & 0.48 & 0.31 & 0.08 \\
\hline $\begin{array}{l}\text { Hopane] } \\
\text { Oleanane Index }\end{array}$ & & & & & & \\
\hline $\begin{array}{l}\text { Oleanane Index } \\
{\left[\left(\text { Oleanane } / \mathrm{C}_{30}\right.\right.} \\
\text { Hopane }) \times 100]\end{array}$ & nd & nd & nd & $14 \%$ & $7 \%$ & $8 \%$ \\
\hline $\mathrm{C}_{29} / \mathrm{C}_{30}$ Hopane Ratio & 0.55 & 1.58 & 0.61 & 0.34 & 0.24 & 0.98 \\
\hline $\mathrm{C}_{27}, \mathrm{C}_{28}, \mathrm{C}_{29}$ & 17,24 & 39,20 , & $49,11,40 \%$ & 37,28 , & 37,25 , & 20,22 , \\
\hline $\begin{array}{l}\text { Sterane Percent } \\
\text { Normal-sterane, Iso- }\end{array}$ & $59 \%$ & $41 \%$ & & $35 \%$ & $38 \%$ & $58 \%$ \\
\hline $\begin{array}{l}\text { sterane, } \\
\text { Rearranged-sterane }\end{array}$ & $\begin{array}{l}37,54 \\
9 \%\end{array}$ & $\begin{array}{l}32,38, \\
30 \%\end{array}$ & $68,21,11 \%$ & $\begin{array}{l}44,43, \\
13 \%\end{array}$ & $\begin{array}{l}66,15 \\
19 \%\end{array}$ & $\begin{array}{l}70,19, \\
11 \%\end{array}$ \\
\hline $\begin{array}{l}\text { Diasterane/Sterane } \\
\text { Ratio }\end{array}$ & 61 & 127 & 22 & 8.5 & 4.6 & 24 \\
\hline $\begin{array}{l}\text { Sterane/Hopane Ratio } \\
20 \mathrm{~S}(20 \mathrm{~S}+20 \mathrm{R})\end{array}$ & 1.10 & 3.80 & 2.02 & 2.49 & 2.93 & 0.90 \\
\hline $\begin{array}{l}\text { Sterane Ratio }\left(\mathrm{C}_{29}\right) \\
\beta \beta /(\beta \beta+\alpha \alpha)\end{array}$ & nd & 0.45 & 0.11 & 0.19 & 0.04 & 0.12 \\
\hline $\begin{array}{l}\text { Sterane Ratio }\left(\mathrm{C}_{29}\right) \\
22 \mathrm{~S} /(22 \mathrm{~S}+22 \mathrm{R})\end{array}$ & nd & 0.51 & 0.22 & 0.19 & 0.16 & 0.08 \\
\hline $\begin{array}{l}\text { Homohopane Ratio } \\
\left(\mathrm{C}_{31}\right)\end{array}$ & 0.55 & 0.56 & 0.44 & 0.36 & 0.49 & 0.36 \\
\hline $\mathrm{Ts} /(\mathrm{Ts}+\mathrm{Tm})$ & 0.50 & 0.32 & 0.25 & 0.21 & 0.17 & 0.19 \\
\hline $\begin{array}{l}\text { Moretane/Hopane } \\
\text { Ratio }\end{array}$ & 0.21 & 0.64 & 0.48 & 0.22 & 0.32 & 0.14 \\
\hline
\end{tabular}

$\mathbf{C}_{35} /\left(\mathbf{C}_{\mathbf{3 1}}-\mathbf{C}_{\mathbf{3 5}}\right)$ Homohopane Index: $(35+36) /(25+26+29+30+31+32+33+34+35+36)$ $(\mathrm{m} / \mathrm{z} 191)$

$\mathbf{C}_{35} / \mathbf{C}_{\mathbf{3 4}}$ Homohopane Ratio: $(35+36) /(33+34)(\mathrm{m} / \mathrm{z} 191)$

Diasterane/Sterane Ratio: $[(1+2) /(8+11)] \times 100(\mathrm{~m} / \mathrm{z} 217)$

Sterane/Hopane Ratio: $(8+9+10+11+14+15+16+17+18+19+20+21)(\mathrm{m} / \mathrm{z} 217) /$

$(18+23+25+26+29+30+31+32)(\mathrm{m} / \mathrm{z} 191)$

20S(20S+20R) Sterane Ratio: $18 /(18+21)(\mathrm{m} / \mathrm{z} 217)$

$\beta \beta /(\beta \beta+\alpha \alpha)$ Sterane Ratio: $(19+20) /(19+20+18+21)(\mathrm{m} / \mathrm{z} 217)$

22S/(22S+22R) Homohopane Index $\left(\mathbf{C}_{32}\right): 29 /(29+30)(\mathrm{m} / \mathrm{z} 191)$

Moretane/Hopane Ratiol: 24/23 (m/z 191)

nd: not determined

Gölpazarı and Bahçecik oil shales, and it is not found in the other areas. High ratios of gammacerane are detected in the Himmetoğlu, Hatıldağ and Gölpazarı oil shale samples, and medium amounts in the Seyitömer, 
Beypazarı and Bahçecik samples (Fig. 4). In general, a homohopane distribution where $\mathrm{C}_{31}$ is dominant is observed in all oil shale samples (except Himmetoğlu where $\mathrm{C}_{32}$ dominates) (Fig. 5). Homohopane distribution typical of Seyitömer, Hatıldağ and Bahçecik oil shales decreases smoothly towards higher numbers. $\mathrm{C}_{35}$ homohopane indexes for the Seyitömer, Himmetoğlu, Hatıldağ, Gölpazarı and Bahçecik oil shale samples are 9, 12, 15, 15 and 12, respectively. $\mathrm{C}_{35} / \mathrm{C}_{34}$ homohopane ratios for Seyitömer, Hatıldağ and Bahçecik are $0.83 ; 0.91$ and 0.45 , respectively.
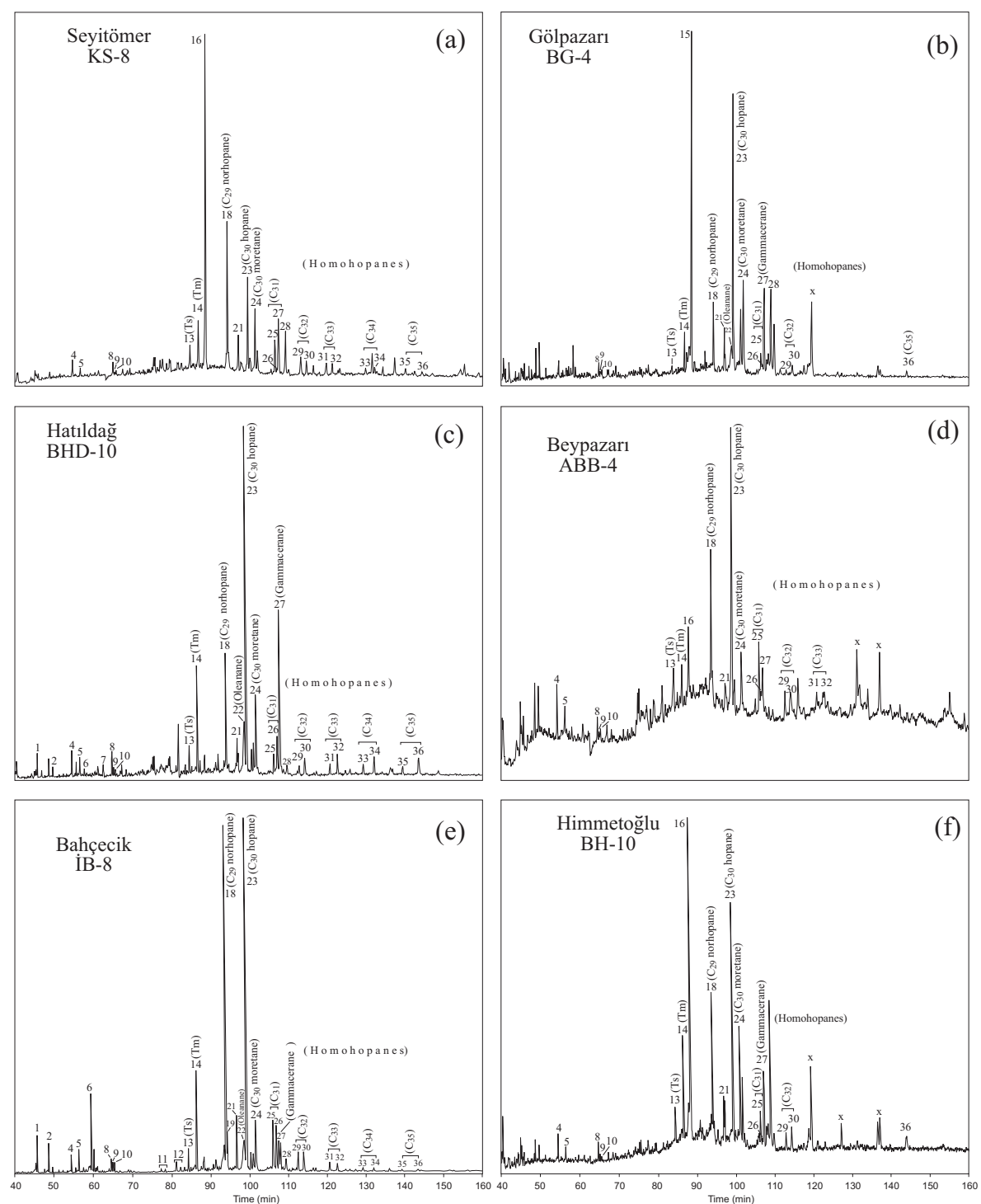

Fig. 4. The m/z 191 mass chromatograms of the selected oil shales (for peak definition see Table 2). 


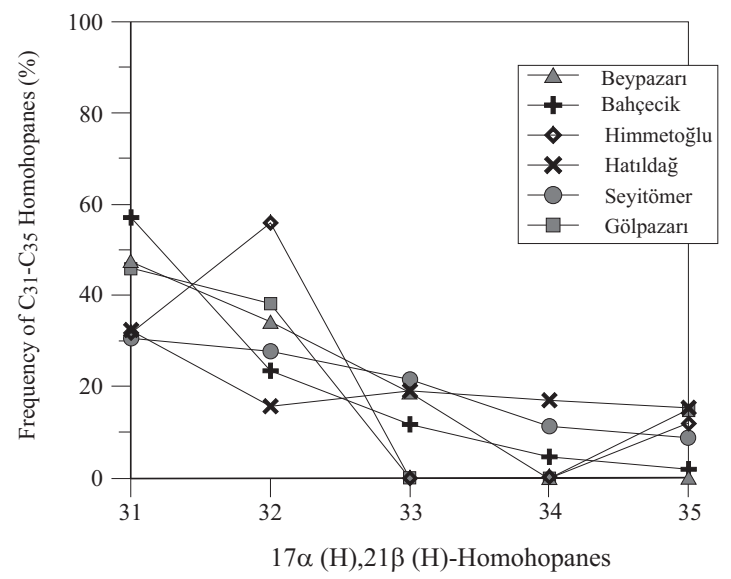

Fig. 5. $\mathrm{C}_{31}-\mathrm{C}_{35}$ homohopane distributions (\%) for the selected oil shale samples.

\section{Type of organic matter}

The type of organic matter in a rock sample can be determined by using the results of pyrolysis, GC and GC/MS. Kerogen types of the oil shale samples are determined by using $\mathrm{S}_{2}$-TOC [10], HI- $\mathrm{T}_{\max }$ [11] and HI-OI [12] kerogen classification diagrams (Figs. 6 and 7).

In the $\mathrm{S}_{2}$-TOC diagram, the Beypazarı, Gölpazarı, Bahçecik oil shales are plotted in the Type I area, Seyitömer in Type II, and the Himmetoğlu, Hatıldağ oil shale samples in the Type I-II area (Fig. 6). In the HI- $\mathrm{T}_{\max }$ and HI-OI diagrams, the samples taken from all the areas are located generally in the Type I area, and only one sample from each of the Seyitömer and Hatıldağ areas in the Type II area (Fig. 7). Accordingly, it is found that the oil shales generally contain Type I kerogen, only the Seyitömer and Hatıldağ

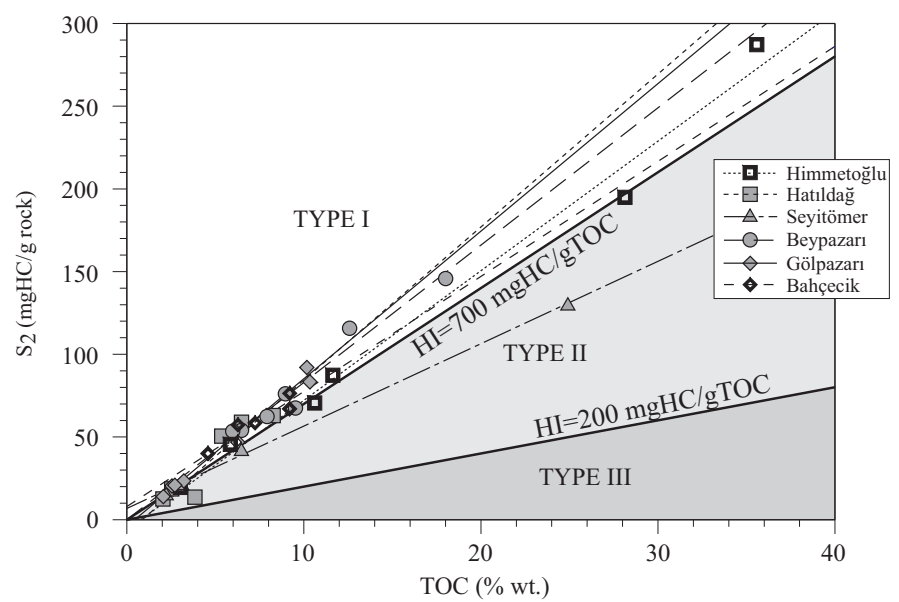

Fig. 6. Distribution of the oil shale samples in $\mathrm{S}_{2} v s$ total organic carbon (TOC) plot. 

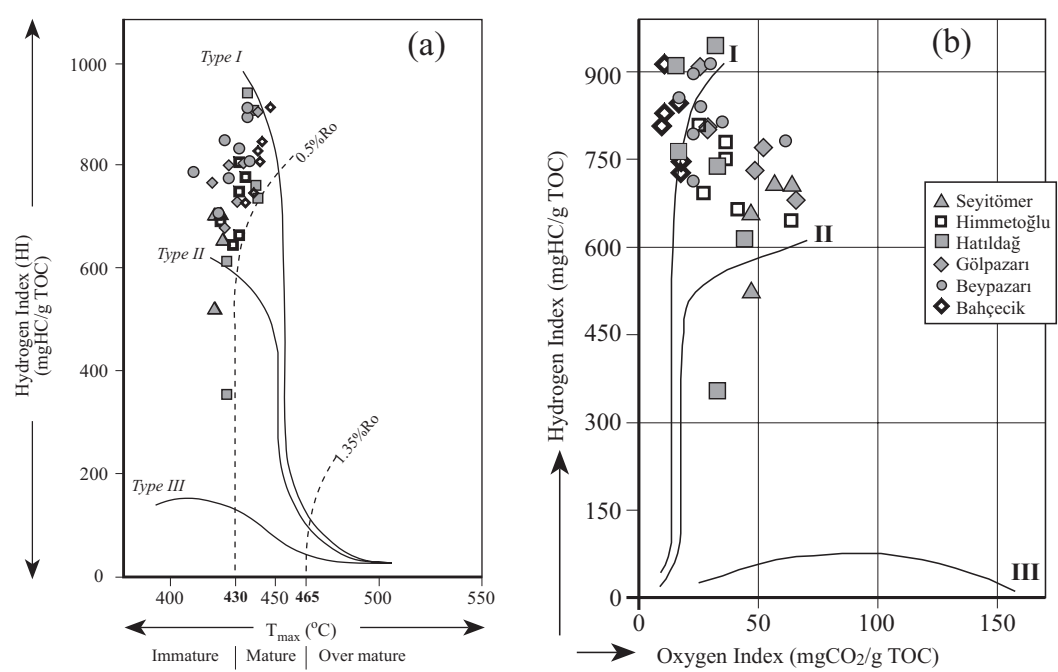

Fig. 7. Distribution of the oil shale samples in HI vs $\mathrm{T}_{\max }$ (a) and HI vs OI (b) plot.

oil shales contain very low ratios of Type II kerogen. Type I kerogen characteristics of all the oil shales imply that they dominantly contain algal (lacustrine) organic matter. The presence of small amounts of Type II kerogen in the Hatıldağ and Seyitömer oil shales is probably caused by spores and pollen of land plants and their leaf and stem cuticles.

Bimodal distribution where the low number $n$-alkanes are dominant is observed in the gas chromatograms of the Himmetoğlu, Hatıldağ, Gölpazarı and Bahçecik oil shale samples. Such a distribution shows the addition of very little amounts of terrestrial organic matter with algal dominance $[13,14]$. Furthermore, the oleanane recorded in $\mathrm{m} / \mathrm{z} 191$ mass chromatograms indicates contribution of organic matter from angiosperms of Cretaceous and younger higher plants [15-19]. Oleanane is detected in the Hatıldağ, Gölpazarı and Bahçecik oil shales (Fig. 4b-c-e) and the oleanane indices calculated are 14, 7 and $8 \%$ respectively. These values show that, according to Hunt's [19] classification, the Hatıldağ oil shales contain a little input of terrestrial organic matter, whereas that in the case of the Gölpazarı and Bahçecik oil shales is unimportant. The fact that the oleanane is not recorded in the $\mathrm{m} / \mathrm{z} 191$ mass chromatograms of the other shales does not indicate that there is no terrestrial input. The sterane/hopane ratio gives an idea about the organic matter input. Steranes originate mainly from algae and higher plants, and hopanes originate from the cell material of bacteria [18]. The sterane/hopane ratio calculated for the Beypazarı, Seyitömer, Himmetoğlu, Hatıldağ, Gölpazarı and Bahçecik oil shales is $1.10 ; 3.80 ; 2.02$; $2.93 ; 1.91$ and 0.90 , respectively. These values show the presence of algal organic matter and dominance of the sterane for the other fields except the Bahçecik oil shales. Abundance of hopane in the Bahçecik oil shales shows the dominance of bacterial organic matter compared to its content of the other oil shales. In general, Type I kerogen characteristic of these oil shales, 
bimodal $n$-alkane distribution where the low carbon number alkanes are more abundant, and the other biomarker data indicate the dominance of algal organic matter and low inputs of bacterial and terrestrial organic matter.

\section{Maturity of organic matter}

The maturity of the organic matter is determined by the creation process of hydrocarbon compounds through undergoing physical and chemical changes by different agents like heat, pressure, burial and time after deposition in a sedimantary basin [13]. Thermal history of the organic matter changes many of its physical and chemical characteristics, and the maturity of the organic matter can be measured by making use of these characteristics. In this work, the maturity of the kerogen is interpreted by using the results of pyrolysis, $\mathrm{GC}$ and GC/MS analysis.

It is found that the $T_{\max }$ value measured during the pyrolysis and the calculated PI values are closely related to thermal history of the organic matter $[13,14]$. The average $T_{\max }$ values calculated for the Beypazar1, Seyitömer, Himmetoğlu, Hatıldağ, Gölpazarı and Bahçecik oil shales are $429,423,432,436,431$ and $442{ }^{\circ} \mathrm{C}$, respectively. These values show that the oil shales, except Bahçecik, are characterized by low $\mathrm{T}_{\max }$ values and show immature characteristics. The average $\mathrm{T}_{\max }$ value of $442{ }^{\circ} \mathrm{C}$ characterizing the Bahçecik oil shales generally reflects the character of early maturity, and it corresponds to the maturity at the entrance into oil generation window [20]. However, considering that these oil shales contain Type I kerogen, it becomes clear that this $T_{\max }$ value is not sufficient for oil generation [13] and it reflects immaturity. The PI values of all oil shales are quite low (Table 3 ), corresponding to the immature character in the maturity classification made by the Production Index [21].

Average values of the bitumen/TOC ratio, calculated for the Beypazarı, Seyitömer, Himmetoğlu, Hatıldağ, Gölpazarı and Bahçecik oil shales, 0.071; $0.043 ; 0.032 ; 0.066 ; 0.034$ and 0.073 , respectively, also reflect their immaturity. Isoprenoids dominate in the gas chromatograms of the Beypazarı and Seyitömer oil shale samples (Fig. 2a-b), and they are also widespread in the Himmetoğlu and Hatıldağ oil shales (Fig. 2c-e). High concentrations observed in the biomarker region of the gas chromatograms of the Beypazarı, Seyitömer and Hatıldağ oil shales (Fig. 2a-b-c) show also low maturity. Furthermore, CPI values which are evidently higher than 1.0 for the Himmetoğlu, Hatıldağ, Gölpazarı and Bahçecik oil shales result from their low maturity degree $[19,20]$.

The $20 \mathrm{~S} /(20 \mathrm{~S}+20 \mathrm{R})$ sterane ratio increases with increasing maturity degree $[17,20,22-25]$. This ratio could not be determined for the Beypazarı area oil shale, as well as for the other areas, due to quite low values that have not reached equilibrium value yet (Table 4 ). Another maturity parameter calculated using the sterane data is the $\beta \beta /(\beta \beta+\alpha \alpha)$ ratio, and this ratio increases with increasing maturity $[14,17,22,23]$. This ratio could not be determined for the Beypazarı area; middle values characterize the Seyitömer 
area and very low values for the other areas are calculated (Table 4). The transformation has not reached the equilibrium in any area. These two ratios calculated for steranes also reflect immaturity of all oil shales.

The $22 \mathrm{~S} /(22 \mathrm{~S}+22 \mathrm{R})$ homohopane ratio increases with maturity $[17,19]$. The equilibrium value for the homohopane ratio is measured to be $0.57-0.62$ [25]. This ratio, which has not reached the equilibrium value for all the areas, reflects the immature characteristics of Turkish oil shales.

The $\mathrm{Ts} /(\mathrm{Ts}+\mathrm{Tm})$ rate also increases in proportion with maturity $[19,26]$, but the moretane/hopane ratio decreases [27-29]. In general, all the oil shale samples are immature enough, according to their low $\mathrm{Ts} /(\mathrm{Ts}+\mathrm{Tm})$ ratio and the moretane/hopane ratio exceeding 0.15 [17].

The maturity data obtained indicate that all the oil shales are immature.

\section{Depositional environment}

Depositional environments of oil shales are interpreted by using the data of the organic geochemical analyses. Biomarkers provide information about the type of the environment where the organic matter deposits, the conditions existing in the depositional environment during the deposition and the litology of the rock in which the organic matter is present. The $17 \alpha(\mathrm{H})$-homohopane distributions change extensively from sample to sample and provide information about the paleoenvironment $[17,30]$. A homohopane distribution with the dominance of low-number homologues is observed in the $\mathrm{m} / \mathrm{z} 191$ mass chromatograms of the oil shale samples (Fig. 4, 9), and homohopane index is very low for all the oil shale samples (Table 4). Such a homohopane distribution with low $\mathrm{C}_{35}$ homohopane index values generally corresponds to a suboxic depositional environment [19]. Furthermore, the homohopane distributions, which have a regular decrease in the peak height from $\mathrm{C}_{31}$ to $\mathrm{C}_{35}$, especially in the Bahçecik, Hatıldağ and Seyitömer oil shales, indicate clastic facieses [17]. The $\mathrm{Pr} / \mathrm{Ph}$ ratio reflects the redox potential of the depositional environment $[20,31]$. The $\mathrm{Pr} / \mathrm{Ph}$ ratio calculated for the Beypazarı, Seyitömer, Himmetoğlu, Hatıldağ, Gölpazarı and Bahçecik oil shales is $0.14 ; 0.17 ; 1.47$; $0.93 ; 1.54$ and 1.52 , respectively. It is evident that the Beypazar1, Seyitömer and Hatıldağ oil shales having a $\mathrm{Pr} / \mathrm{Ph}$ ratio lower than 1.0 have been deposited in an anoxic environment. The homohopane and $\mathrm{Pr} / \mathrm{Ph}$ data evaluated together indicate that the Himmetoğlu, Gölpazarı and Bahçecik oil shales are the products of a suboxic depositional environment.

The $\mathrm{C}_{29} / \mathrm{C}_{30}$ hopane ratio is used to distinguish the carbonate and clastic lithology [17,32], The ratios measured for the Beypazar1, Seyitömer, Himmetoğlu, Hatıldağ, Gölpazarı and Bahçecik oil shales are 0.55; 1.58; $0.61 ; 0.34 ; 0.24$ and 0.98 , respectively, and these values indicate clastic rocks, except Seyitömer. The $\mathrm{C}_{29} / \mathrm{C}_{30}$ ratio higher than 1.0 characterizing the Seyitömer oil shales shows that they contain much carbonate components; this conclusion concurs with the fact that the Seyitömer oil shales contain actually marl as has been indicated in literature many times. 
Gammacerane, which is a typical biomarker for the lake and sea sediments of high salinity $[17,19,20,33]$, is recorded in higher abundances for the Himmetoğlu, Hatıldağ, Gölpazarı and Seyitömer oil shales, in medium abundances for the Beypazarı and Bahçecik oil shales. The gammacerane index characterizing these shales is $0.32 ; 0.48 ; 0.31 ; 0.54 ; 0.13$ and 0.08 , respectively. Furthermore, the pregnanes that are another indicator of salinity are present in low quantities in the Bahçecik and Hatıldağ oil shales, in medium amounts in the Seyitömer, Himmetoğlu and Gölpazarı oil shales, and in abundance in the Beypazar1 oil shales (Fig. 3). The presence of both gammacerane and pregnane shows that all the oil shales have been deposited in a saline environment.

The $\mathrm{C}_{25} / \mathrm{C}_{26}$ tricyclic terpane ratio is used to distinguish the marine and non-marine environments [34-36]. The values higher than 1.0 indicate a marine environment, whereas the low values a non-marine environment. This ratio calculated for the Hatıldag oil shale sample is 0.82 . As the $C_{25}$ tricyclic terpane is not recorded in the oil shales from the other areas, the ratio could not be calculated. The ratio lower than 1.0 calculated for the Hatıldag oil shales and the existence of $\mathrm{C}_{26}$ tricyclic terpane without recording $\mathrm{C}_{25}$ tricyclic terpane for the other areas indicate that all the oil shales are the products of a non-marine depositional environment. Basing on the data about lithology and fossils of the oil shales in the former studies performed in these areas, it was suggested that they have been deposited in a lacustrine environment $[1-3,6,8,37,38]$. The biomarker and the other data obtained in this study also indicate a lacustrine depositional environment.

\section{Potential of hydrocarbon generation}

The potential yield (PY) parameter calculated by adding $S_{1}$ and $S_{2}$ values gives an idea about the hydrocarbon generation potential of a rock [13]. PY values of the Beypazarı, Seyitömer, Himmetoğlu, Hatıldağ, Gölpazarı and Bahçecik oil shale samples range between 16.53-153.38, 16.86-114.77, 20.94-301.51, 13.48-64.02, $14.53-95.6$ and $40.71-78.86 \mathrm{mgHC} / \mathrm{g}$ rock, respectively, and the average values are $78.99 ; 50.21 ; 124.07 ; 37.49 ; 43.98$ and $59.54 \mathrm{mgHC} / \mathrm{g}$ rock. In general, the oil shales of all the areas are characterized by a rather high PY values. However, Himmetoğlu oil shales show rather high values in comparison with the others. The high PY values indicate that hydrocarbon generation potential of the oil shales is rather high.

The average hydrogen index (HI) values of the the Beypazarı, Seyitömer, Himmetoğlu, Hatıldağ, Gölpazarı and Bahçecik oil shale samples are 822, $648,723,720,781$ and $812 \mathrm{mgHC} / \mathrm{gTOC}$, respectively. Such high HI values show that (Type I kerogen) oil shales have a potential to generate oil [21, 39]. Furthermore, $\mathrm{S}_{2} / \mathrm{S}_{3}$ rate is found to be rather high for all the areas, and this rate higher than 5 also indicates that these oil shales can generate oil [21].

Therefore, the formation of crude oil was not possible due to immature nature of the oil shales, although hydrocarbon potential of the oil shales of all the areas is high. 


\section{Conclusions}

The average TOC values of the Beypazarı, Seyitömer, Himmetoğlu, Hatıldağ, Gölpazarı and Bahçecik oil shales are determined to be 8.91; 9.17; $15.81 ; 4.75 ; 5.17$ and $7.15 \%$, respectively. These TOC values show that organic matter content of the oil shales is very high.

HI-OI, HI- $\mathrm{T}_{\max }$ and $\mathrm{S}_{2}$-TOC kerogen type classification diagrams indicate that the Beypazarı, Himmetoğlu, Gölpazarı and Bahçecik oil shales contain Type I kerogen; the Seyitömer and Hatıldağ oil shales contain also Type I kerogen dominantly and Type II kerogen in small quantities. These kerogen types indicate the dominance of algal (lacustrine) organic matter. Gas chromatograms of the Himmetoğlu, Hatıldağ, Gölpazarı and Bahçecik oil shales all show bimodal distributions. The dominance of low carbon-number $n$-alkanes indicates that these oil shales consist mainly of algal and less of terrestrial organic matter. The oleanane index for the Hatıldağ, Gölpazarı and Bahçecik oil shales also indicates that there is very little input of terrestrial organic matter.

The PY values calculated for the Beypazarı, Seyitömer, Himmetoğlu, Hatıldağ, Gölpazarı and Bahçecik oil shales are 78.99; 50.21; 124.07; 37.49; 43.98 and $59.54 \mathrm{mgHC} / \mathrm{g}$ rock. Basing on these values, it is concluded that the oil shales are the source rocks with high hydrocarbon potential. High HI values and high $\mathrm{S}_{2} / \mathrm{S}_{3}$ ratios of oil shale samples from all fields show that oil shales have a potential to generate oil.

The $T_{\max }$ values of pyrolysis of the Beypazarı, Seyitömer, Himmetoğlu, Hatıldağ, Gölpazarı and Bahçecik oil shales are 429, 423, 432, 436, 431 and $442{ }^{\circ} \mathrm{C}$, respectively. According to these values, all the oil shales are immature. In addition to gas chromatograms, m/z 217 and m/z 191 mass chromatograms also indicate that these oil shales are immature. Therefore, their alteration to form crude oil was not possible due to immature nature, although the oil shales of all the areas are characterized by high hydrocarbon potential.

The $\mathrm{Pr} / \mathrm{Ph}$ ratios of the Beypazarı, Seyitömer, Himmetoğlu, Hatıldağ, Gölpazarı and Bahçecik oil shales show that the Beypazarı, Seyitömer and Hatıldağ oil shales have been deposited in an anoxic and the Himmetoğlu, Gölpazarı and Bahçecik oil shales in a suboxic environment.

Gammacerane was recorded in higher abundances for the Himmetoğlu, Hatıldağ, Gölpazarı and Seyitömer oil shales and in medium abundances for the Beypazarı and Bahçecik shales. According to the gammacerane presence and other parameters, all the oil shales may be considered to have been deposited in a saline environment.

The $\mathrm{C}_{25} / \mathrm{C}_{26}$ tricyclic terpane ratio lower than 1.0 calculated for the Hatıldag oil shales and the existence of $\mathrm{C}_{26}$ tricyclic terpane without recording $\mathrm{C}_{25}$ tricyclic terpane for the other areas indicate that all the oil shales are the products of a non-marine depositional environment. Basing on the data about lithology and fossils of the oil shales in the former studies 
performed in these areas, it can be said that they have deposited in a lacustrine environment. The biomarker and the other data obtained in this study also indicate a lacustrine depositional environment.

Basing on the whole geochemical data which is mentioned above in detail, the oil shales studied from Northwest Anatolia, were deposited in a similar depositional environment and conditions.

\section{Acknowledgements}

This work was supported by the Research Fund of Karadeniz Technical University (KTU) and AAPG Foundation. Analyses were carried out by TPAO (Turkish Petroleum Corp.) Organic Geochemistry Labs. Some samples were obtained from MTA (General Directorate Mineral Research and Exploration). In addition, this study was supported by Senior Geologist H. İztan (TPAO), Dr. N. Tüysüz (KTU) and Lec. A. Abduloğlu (KTU). We thank all these people and organizations.

\section{REFERENCES}

1. Talu, S. Oil shale of Bahçecik (İzmit) // Report No. 4667, MTA, Ankara, 1967 (unpubl.) [in Turkish].

2. Yanılmaz, E., Ipeksever, M., Aslan, N. Report on Gölpazar1 (Bilecik) oil shale field // Report No. 7060, MTA, Ankara, 1980 (unpubl.) [in Turkish].

3. Taka, M., Şener, M. Oil shale facility of Himmetoğlu (Göynük-Bolu) field and their wells // Report No. 8533, MTA, Ankara, 1988 (unpubl.) [in Turkish].

4. Şener, M., Şengüler, İ. Geology and economic usage of Beypazarı oil shale// Report No. 9202, MTA, Ankara, 1991 (unpubl.) [in Turkish].

5. Şener, M., Şengüler, $\dot{I}$. Geology, usage facility and firing test results in fluid bed of Seyitömer oil shale // Report. No. 9441, MTA, Ankara, 1992 (unpubl.) [in Turkish].

6. Şener, M., Şengüler, $\dot{I}$. Geology and technologic usage facility of Hatıldağ (BoluGöynük) oil shale// Report No. 9445, MTA, Ankara, 1992 (unpubl.) [in Turkish].

7. Şener, M., Şengüler, I., Kök, M. V. Geological consideration for the economic evaluation of oil shale deposits in Turkey // Fuel.1994. Vol. 74, No. 7. P. 999 1003.

8. Özçelik, $O$. Organic geochemical characteristics of Miocene bituminous units, North of Beypazarı (Ankara) // Geology Bulletin of Turkey. 2002. Vol. 45, No. 1. P. 1-17 [in Turkish with English abstract].

9. Sarl, A. Economic geology of lignite field in the Himmetoğlu village (GöynükBolu) // Master Thesis, Ankara University, Science Faculty, Ankara, 1985 (unpubl.) [in Turkish with English abstract]. 
10. Langford, F. F., Blanc-Valleron, M. M. Interpreting Rock-Eval pyrolysis data using graphs of pyrolizable hydrocarbons vs. total organic carbon// AAPG Bulletin. 1990. Vol. 74. P. 799-804.

11. Mukhopadhyay, P. K., Wade, J. A., Kruge, M. A. Organic facies and maturation of Jurassic/Cretaceous rocks, and possible oil-source rock corelation based on pyrolysis of asphaltenes, Scotion Basin, Canada // Org. Geochem. 1995. Vol. 22, No. 1. P. 85-104.

12. Espitalie, J., Madec, M., Tissot, B. Source rock characterization $/ / 9^{\text {th }}$ Offshore Technology Conference. Houston, 1977. Vol. 3. P. 439-444.

13. Tissot, B. P., Welte, D. H. Petroleum Formation and Occurence. - Berlin: Springer Verlag, 1984.

14. Waples, D. W. Geochemistry in Petroleum Exploration. - Boston: D. Reidel Publ. Comp., 1985.

15. Ekweozor, C. M., Udo, O.T. The oleananes: Origin, maturation and limits of occurence in southern Nigeria sedimentary basins // Advances in Organic Geochemistry 1987 / L. Mattavelli, L. Novelli (eds.). Oxford: Pergamon Press, 1988. P. 131-140.

16. Riva, A., Caccialanza, P. G., Quagliaroli, F. Recognition of $18 \beta(\mathrm{H})$ oleanane in several crudes and Tertiary-upper Cretaceous sediments. Definition of a new maturity parameters // Advances in Organic Geochemistry 1987 / L. Mattavelli, L. Novelli (eds.). Oxford: Pergamon Press,1988. P. 671-675.

17. Waples, D. W., Machihara, T. Biomarkers for Geologists: A Pratical Guide to the Application of Steranes and Triterpanes in Petroleum Geology.-AAPG Methods in Exploration, 9. 1991.

18. Peters, K. E., Walters, C. C., Moldowan, J. M. The Biomarker Guide. Vol. 2: Biomarkers and Isotopes in Petroleum Exploration and Earth History. 2rd ed. Cambridge, 2004. P. 475-1155.

19. Hunt, J. M. Petroleum Geochemistry and Geology. - New York: W. H. Freeman and Company, 1995.

20.Peters, K. E., Moldowan, J. M. The Biomarker Guide: Interpreting Molecular Fossils in Petroleum and Ancient Sediments. - New Jersey: Prentice-Hall, 1993.

21. Merrill, R. K. Source and Migration Processes and Evaluation Techniques/ R. K. Merrill (ed). - Oklahoma: AAPG, 1991.

22. Mackenzie, A. S., $\quad$ Patience, R. L., $\quad$ Maxwell, J. R., $\quad$ Vandenbroucke, M., Durand, B. Molecular parameters of maturation in the Toarcian shales, Paris Basin, France. 1. Changes in the configurations of cyclic isoprenoid alkanes and triterpanes // Geochim. Cosmochim. Acta. 1980. Vol. 44, No. 11. P.1709-1721.

23. Spiro, $B$. Effects of the mineral matrix on the distribution of geochimical markers in thermally affected sedimentary sequences // Org. Geochem. 1984. Vol. 6. P. 543-559.

24. Seifert, W. K., Moldowan, J. M. Paleoconstruction by biological markers // Geochim. Cosmochim. Acta. 1981. Vol. 45, No. 6. P. 783-794.

25. Seifert, W. K., Moldowan, J. M. Use of biological markers in petroleum exploration // Methods in Geochemistry and Geophysics. Vol. 24/ P. B. Johns (ed.). 1986. P. 261-290. 
26. Seifert, W. K., Moldowan, J. M. Applications of steranes, terpanes, and monoaromatics to the maturation, migration, and source of crude oils // Geochim. Cosmochim. Acta. 1978. Vol. 42, No. 1. P. 77-95.

27. Kvenvolden, K. A., Simoneit, B. R. T. Hydrothermally derived petroleum examples from Guaymas Basin, Gulf of California, and Escanaba Trough, northeast Pacific Ocean // AAPG Bulletin. 1990. Vol. 74. P. 223-237.

28. Seifert, W. K., Moldowan, J.M. The effect of thermal stress on source rock quality as measured by hopane stereochemistry // Advances in Organic Geochemistry / A. G. Douglas, J. R. Maxwell (eds.). - Oxford: Pergamon Press, 1980. P. 229-237.

29. Grantham, $P$. J. Sterane isomerisation and moretane/hopane ratios in crude oils derived from Tertiary source rocks // Org. Geochem. 1986. Vol. 9, No. 6. P. 293-304.

30. Wang, H. D., Philp, R. P. Geochimical study of potential source rocks and crude oils in the Anadorka Basin, Oklahoma // AAPG Bulletin.1997. Vol. 81. P. 249275.

31.Didyk, B. M., Simoneit, B. R. T., Brassell, S. C., Eglinton, G. Organic geochemical indicators of palaeoenvironmental conditions of sedimentation // Nature. 1978. Vol. 272, No. 5650. P. 216-222.

32. Riva, A., Riolo, J., Mycke, B., Ocampo, R., Callot, H. J., Albrecht, P., Nali, M. Molecular parameters in Italian carbonate oils: Reconstruction of past depositional environments $/ / 14^{\text {th }}$ International Meeting on Organic Geochemistry. Paris, September 18-22, Abstracts, Number 335, 1989.

33. Connan, J. Molecular geochemistry in oil exploration // Applied Petroleum Geochemistry / M. L. Bordenave (ed.). - Paris, 1993. P. 175-204.

34. Burwood, R., Leplat, P., Mycke, B., Paulet, J. Rifted margin source rock depositon: A carbon isotope and biomarker study of a West African lower cretaceous "Lacustrine" section // Org. Geochem. 1992. Vol. 19, No. 1-3. P. 41-52.

35. Hanson, A. D. Organic Geochemistry and Petroleum Geology, Tectonics and Basin Analysis of Southern Tarim and Northern Qaidam Basin, Northwest China // Ph.D. Thesis, Stanford University, Stanford, California; 1999.

36. Hanson, A. D., Z Zhang, S. C., $\quad$ Moldowan, J. M., Liang, D. G., Zhang, B. M. Molecular organic geochemistry of the Tarim Basin, Northwest China // AAPG Bulletin. 2000. Vol. 84. P.1109-1128.

37. Şengüler, I., Ipeksever, M., Sümer, A. Geology and economic facility of Seyitömer (Kütahya) oil shale field // Report No. 7324, MTA, Ankara, 1982.

38. Şener, M., Şengüler, $\dot{I}$. Geological, mineralogical and geochemical characteristics of oil shale bearing deposits in the Hatıldağ oil shale field, Göynük, Turkey // Fuel. 1997. Vol. 77, No. 8. P. 871-880.

39. Mann, U., Korkmaz, S., Boreham, C.J., Hertle, M., Radke, M., Wilkes, H. Regional geology, depositional environment and maturity of organic matter of Early to Middle Jurassic coals, coaly shales and claystones from the Eastern Pontides, NE Turkey // Int. J. Coal Geol. 1998. Vol. 37, No. 3-4. P. 257-286. 